\title{
External and Internal Influences on \\ R\&D Alliance Formation: Evidence from German SMEs
}

\author{
Debmalya Mukherjee \\ Department of Management \\ College of Business Administration, University of Akron, Akron, OH 44325, USA \\ Tel: 1 330-972-7039, Fax: 1 330-972-6886 (Email: dmukher@uakron.edu)
}

\author{
Ajai S. Gaur \\ Department of Management and Global Business \\ Rutgers Business School, 1 Washington Park, Newark, NJ 07102, USA \\ Tel: 1 732-253-0490, Fax: 1 973-353-1664 (Email: ajai@ business.rutgers.edu) \\ Sanjaya S. Gaur \\ AUT Business School, Auckland University of Technology \\ Private Bag 92006, Auckland 1142, New Zealand \\ Tel: 0064-9-9219999 Ext. 5465, Fax: 0064-9-9219990 (Email: sgaur@aut.ac.nz)
}

\author{
Florian Schmid \\ Roland Berger Strategy Consultants \\ Arabellastraße 33, D - 81925 München, Germany
}

Tel: 49899230 8973, Fax: 498992308264 (Email: florianschmid @de.rolandberger.com)

\section{Forthcoming, Journal of Business Research}

Suggested citation:

Mukherjee, D., Gaur, A. S., Gaur, S. S., \& Schmid, F. 2012 External and internal influences on R\&D alliance formation: Evidence from German SMEs. Forthcoming, Journal of Business Research. 


\title{
External and internal influences on R\&D alliance formation: \\ Evidence from German SMEs
}

\begin{abstract}
Relying on relational capital theory and transaction cost economics (TCE), this study identifies factors that impede or promote alliance formation in small to medium-sized enterprises (SMEs). Environmental uncertainty and knowledge intensity impede firms' R\&D alliance formation; the focal firm's overall trust in partners enhances alliance formation. Trust interacts positively with environmental uncertainty and knowledge intensity to affect alliance formation in SMEs. The findings reflect data from a longitudinal sample of 854 German SMEs, captured over eight years from 1999 to 2007.
\end{abstract}

Keywords: Trust, Knowledge Intensity, Environmental Uncertainty, Alliance, R\&D, SMEs 


\section{Introduction}

Firms engage increasingly in collaborative, interfirm alliances to complement and supplement internal activities and to create a bridge with the external environment (Doz and Hamel, 1998; Faems, Janssens, Madhok, and VanLooy, 2008; Marino, Lohrke, Hill, Weaver, and Tambunan, 2008). Extant literature identifies several benefits of alliances, including a stronger competitive position through greater market power (Kogut, 1991), increased efficiencies (Ahuja, 2000), access to new or critical resources or capabilities (Lee, 2007; Rothermael and Boeker, 2008), new market entry, and new products (Lai and Chang, 2010). These benefits lead scholars to suggest that firms form alliances to fulfill resource needs, such as access to new assets (Hagedoorn and Schakenraad, 1990; Nohria and Garcia-Pont, 1991), and learning from partners (Baum, Calabrese, and Silverman, 2000; Kogut, 1988). However, if the benefits from alliances are ubiquitous, why don't all firms form alliances (Ahuja, 2000)? The answer may involve the costs of alliance formation, which relate to the uncertainty associated with future relationships and arise from both firm-specific factors and the environment in which a firm operates.

Firms do not base alliance decisions solely on resource requirements; rather environmentspecific and firm-specific factors interact and jointly determine a firm's alliance decision (Koza and Lewin, 1998; Park, Chen, and Gallagher, 2002). By entering an alliance, the firm opens itself to opportunistic behaviors by partners (Parkhe, 1993). This concern is especially salient for small to medium-sized enterprises (SMEs) with knowledge-based products and technologies that have relatively less bargaining power than large firms (Lavie, 2007). In addition to firm-specific factors, a high level of environmental uncertainty may deter SMEs from engaging in alliances. To alleviate such concerns, trust often plays a central role early by mitigating apprehensions of 
potential opportunistic behaviors (Adobor, 2005). In turn, SMEs' relational capital, in the form of inter-partner trust, should encourage alliances and reduce concerns related to knowledge leakage and uncertainty.

Several scholars recommend extending this approach to understand firm motivations to engage in alliances (Wassmer, 2010). For example, Park and Zhou (2005: 550) urge researchers to "delineate the direct relationships between the specific attributes of a firm and environment and the firm's alliance decisions" by identifying how "internal and external attributes would interact with each other to determine a firm's response to competitive dynamics by forming alliances with others." The present study responds to those calls with a joint consideration of the influence of firm-specific and environmental factors, integrating arguments from transaction cost economics (TCE) with relational capital theory. Specifically, a firm's general level of trust toward business partners should facilitate the formation of R\&D alliances. Knowledge intensity and environmental uncertainty from TCE likely impede SME alliance formation, whereas interpartner trust is a relational resource that encourages alliance formation. The TCE-based explanations also are contingent on the level of interpartner trust. Accordingly, this research adds to literature on antecedents of alliance formation (e.g., Lohrke, Kreiser, and Weaver, 2006; Marino et al., 2008) by using actual alliance formation likelihood as a dependent variable in a longitudinal setting. Furthermore, uncertainty related to misappropriation of firm-specific resources is more salient when environmental uncertainty is high and the alliances are knowledge intensive. Because trust may help firms cooperate despite uncertainty (e.g., Dyer and Chu, 2003), research that examines such contexts can produce useful insights into when the net benefits of trust are possible. Finally, SMEs differ from their larger counterparts in terms of higher resource constraints (Beckman, Haunschild, and Phillips, 2004; Krishnan, Martin, and 
Noorderhaven, 2006), and this examination of German SMEs provides a useful departure from large, U.S. firm-oriented studies.

The longitudinal data represent 3,694 firm-year observations of German SMEs, gathered in two extensive surveys conducted in 2003 and 2007. As expected, environmental uncertainty has a negative influence, and trust has a positive impact on SME R\&D alliance formation. Further, greater levels of interpartner trust positively moderate and change the direction of the relationship between knowledge intensity and alliance formation; a higher level of interpartner trust weakens the negative effect of environmental uncertainty on R\&D alliance formation.

\section{Conceptual background}

In interfirm alliances, independent firms collaborate to exchange, share, and jointly develop products, services, or technologies (Lavie, Lechner, and Singh, 2007; Teng, 2007). The interorganizational designs are often strategic in nature, providing "the means by which a firm seeks to implement, in part or in whole, elements of management's strategic intent" (Ariño, 2003: 67). To co-create value, firms form alliances with business partners, customers, and even competitors (Doz and Hamel, 1998; Ybarra and Turk, 2009) and thus may be able to generate new products, reduce costs, and expand into newer markets (Faems et al., 2008; Lai and Chang, 2010). Alliances also provide conduits of technology and organizational learning (Johnson and Sohi, 2003). Thus firms engaged in alliance activities report $11 \%$ higher revenue and $20 \%$ higher growth rates than standalone firms (Ybarra and Turk, 2009).

Firms form alliances for two compelling reasons. First, research based on economics and strategic management posits that resource complementarity, quests for power, and the potential of synergistic value creation may drive firms to form alliances (Nohria and Garcia-Pont, 1991; Wassmer, 2010). Second, sociological perspectives argue that social structures play important 
roles in alliance formation, and firms' direct and indirect relational experiences assist the formation of future ties (Adobor, 2005; Gulati, 1999; Gulati and Gargiulo, 1999). In either case, alliances are engines of value creation, and yet not all firms engage in alliances. Extant literature does not provide satisfactory answer as to why (Ahuja, 2000).

To answer this question, the present study examines factors that prevent firms from engaging in alliances. Unlike the resource-based view, which focuses mainly on the benefits of alliances, TCE notes problems related to uncertainty and the risk of opportunistic behavior by alliance partners (Gulati, 1995; Li, Eden, Hitt, and Ireland, 2008; Williamson, 1985, 1991). This theory also posits that the threats of opportunism and misappropriation increase with greater levels of environmental uncertainty. Transaction costs consist of both ex ante forms-such as developing, drafting, and negotiating agreements with appropriate safeguards and the risk of adverse selection — and ex post types—such as the costs to execute, scrutinize, and maintain contracts or deal with moral hazard, holdup, and maladaptation. Firms try to reduce both the $e x$ ante and ex post costs and the underlying uncertainty, by choosing an appropriate governance form, such as standalone status versus alliance formation (Williamson, 1996).

Uncertainty can emanate from the environment (environmental uncertainty) or potential threats of opportunistic behavior by partners (behavioral uncertainty). The threat of opportunistic behavior becomes particularly salient in technology-intensive alliances (Krishnan et al., 2006; Li et al., 2008). Again, the threats of opportunism and misappropriation increase with higher levels of environmental uncertainty. Ex ante, when faced with higher levels of uncertainty firms monitor potential partner activities more intensively (e.g., excessive contingency clauses); $e x$ post, when faced with unforeseen contingencies, they also likely engage in renegotiation. Thus TCE suggests that at higher levels of uncertainty, and when faced with a strategic dilemma about 
whether to engage in an alliance or not, the focal firms prefer standalone status to hedge against proprietary knowledge leaks, loss of control, or inflexibility (Krishnan et al., 2006; Sutcliffe and Zaheer, 1998).

Reliance on trust-based relational governance may provide a way to deal with such contingencies (Dyer and Chu, 2003; Dyer and Singh, 1998). Thus knowledge-specific alliances and their potential for misappropriation entail the central constructs of TCE, uncertainty and asset specificity (Chen and Chen, 2003; Pisano, 1990; Sampson, 2004). Accordingly, environmental uncertainty and a firm's knowledge intensity should affect the firm's likelihood to form an alliance, as well as the extent to which the firm's trust in business partners influences that decision. This reasoning reflects the recognition that firms base their alliance decisions on resource requirements, as well as environmental and firm-specific factors (Koza and Lewin, 1998; Park et al., 2002). Also, SMEs should note the strong potential for opportunistic behaviors by larger or wealthier partners, especially if those SMEs rely on knowledge-intensive products and technologies (Lavie, 2007). If SMEs also discern high environmental uncertainty, the firms are unlikely to enter alliances, which would increase overall uncertainty. However, if the SMEs participate in trust-based alliance relations, a form of relational capital, the firms should experience fewer knowledge misappropriation concerns and uncertainty and thus engage in alliances.

\section{Hypotheses development}

\subsection{Environmental uncertainty and alliance formation}

A perceived inability to evaluate and predict future changes in external environmental conditions indicates environmental uncertainty (Dess and Beard, 1984; Dickson and Weaver, 1997; Milliken, 1987), which exerts significant influences on organizational processes and 
strategy (Dollinger and Golden, 1992; Marino et al., 2008; Walker and Weber, 1987) and plays a pivotal role in alliance formation. However, empirical research offers mixed findings regarding the strength and direction of the influence of environmental uncertainty on alliance formation, perhaps due to the multidimensional nature of the construct. ${ }^{1}$ Dickson and Weaver (1997) find that though general, technological, and internationalization uncertainty increase the likelihood of alliances, customer demand and competitor uncertainty are impediments. Dollinger and Golden (1992) categorize environmental uncertainty into munificence, dynamism, and complexity; munificence and complexity increase alliance usage, but environmental dynamism has no significant effect.

Research that advocates a positive relationship between environmental uncertainty and alliance formation (e.g., Dollinger and Golden, 1992; Dickson and Weaver, 1997) asserts that collaborative designs reduce uncertainty through shared risks, pooled resources, attenuated competition, and new market opportunities (Dickson and Weaver, 1997; Kale and Singh, 2009). However, concerns related to the misappropriation of strategic assets remain a central feature of interfirm collaborations (Kale, Singh, and Perlmutter, 2000), which increase in conditions of heightened uncertainty associated with unpredictable changes in market demands, competition, and technology. Such dynamic environments may discourage firms, especially SMEs, from forming alliances.

First, unpredictability and sudden changes in the external environment increase information processing demands (Tushman and Nadler, 1978) and even may force firms to alter their strategic postures. Inherent uncertainties associated with alliances include opportunistic behaviors, uncertain costs and benefits, and management ambiguities (Chung, Singh, and Lee, 2000). Luo (2007) shows that alliance partners' opportunism depends on environmental volatility

\footnotetext{
${ }^{1}$ We are thankful to an anonymous reviewer for suggesting this to us.
} 
and increases with rising uncertainty in the environment. These uncertainties are particularly prominent in R\&D alliances, which demand relationship-specific and other types of resource commitments to succeed.

Environmental uncertainty also requires "organizations to engage in significant scanning of their environment in search of accurate and reliable information that enables them to interpret and act upon the threats and opportunities facing them" (Krishnan et al., 2006: 897). Alliance formation and management initiates a series of important processes: partner selection, contract negotiation, mode selection, knowledge and process coordination, performance monitoring, performance evaluation, and so on (Kale and Singh, 2009). These processes entail significant $e x$ ante and ex post transaction costs. When environmental uncertainty is high, managers of SMEs, already burdened by significant information processing demands, may have more difficultly assessing the future value of an R\&D alliance, which increases ex ante transaction costs. Larger firms with more resources can deal with this difficult environment, but smaller firms with resource constraints cannot adapt easily to uncertain environments (Hrebiniak and Joyce, 1985; Podolny, 1994). Thus SMEs may prefer to deploy their limited resources to tackle environmental uncertainty rather than create more uncertainty by forming alliances. Consistent with this, Krishnan et al. (2006) find that SMEs are less likely to create strategic alliances when the market is uncertain. Therefore,

H1: The level of environmental uncertainty that SMEs face relates negatively to the likelihood of alliance formation.

\subsection{Knowledge intensity and alliance formation}

Knowledge is an important strategic resource (Grant, 1996). Knowledge intensity refers to the extent to which the production process of the focal firm involves specialized and unique knowledge or technology that may provide a competitive advantage (Autio, Sapienza, and 
Almeida, 2000; Subramani and Venkatraman, 2003). Knowledge intensity arises from the development of production process-specific routines and operating procedures that ensure the efficient and effective production of outputs.

Because $R \& D$ alliances often involve upstream sharing of tacit knowledge and the development of new knowledge (Lavie and Rosenkopf, 2006), opportunities for misappropriation and leakage arise. Firms that possess more knowledge-intensive outputs thus may be cautious in creating R\&D alliances (Kale et al., 2000; Sampson, 2004). Lavie (2007) suggests that not all firms have the same ability to appropriate value from alliances but that appropriation capacity depends on the firm's relative bargaining power. With their smaller resource base and size, SMEs tend to have relatively less bargaining power in alliances. In turn, SMEs face the risk of being too dependent on partners or losing crucial strategic information during alliance formation (Chi, 1994; Hamel, 1991), to the possible detriment of a competitive advantage (Bleeke and Ernst, 1995).

For these reasons, SMEs may hesitate to engage in $\mathrm{R} \& \mathrm{D}$ alliances and prefer to retain knowledge-intensive activities under their own umbrella (Chen and Chen, 2003). Hierarchical control has advantages over alliances or market control in terms of exploiting asset interdependencies that can lead to a sustainable advantage (Conner and Prahalad, 1996). Because of the shared language and routines that develop within firms, tighter coordination between existing know-how and incoming knowledge is possible with hierarchical control than market control (Ghoshal and Moran, 1996).

Knowledge-intensive activities thus tend to remain in-house, maintained to create dynamic capability. Such activities or resources also allow the firm to configure effectively in response to dynamic, turbulent environments. Researchers suggest a cautious approach to 
determining which business functions or processes to outsource or keep under hierarchical control (Steensma and Corley, 2001). R\&D alliances are created mainly for new product development and are characterized by higher level of interdependencies (Sampson, 2004.). Interdependencies may require partner firms to share valuable knowledge-intensive resources and be subject to hold-up problems (Chen and Chen, 2003; Park and Russo, 1996). Shared knowledge-intensive resources also increase the potential for misunderstandings about each partner's intents and contributions to the alliance. With their size, SMEs have little bargaining power over larger firms and fewer resources to search for reliable alliance partners to alleviate opportunism concerns. Therefore, SMEs with knowledge-intensive resources should be tentative about forming R\&D alliances. In other words,

H2: An SME's existing level of knowledge intensity relates negatively to the likelihood of alliance formation.

\subsection{Trust and alliance formation}

Trust has received significant attention in the organizational literature (Gaur, Mukherjee, Gaur and Schmid, 2011). Lewicki et al. (1998: 439) define trust as "confident positive expectations regarding another's conduct." In the context of a dyadic relationship trust refers to focal firm's expectation that the exchange partner will not act opportunistically (Gulati and Nickerson, 2008). Distinguishing between interpersonal trust and interorganizational trust, Zaheer, McEvily, and Perrone (1998: 143) argue that the latter "describes the extent to which organizational members have a collectively held trust orientation towards the partner firm." As a multidimensional construct, trust may also have competence and intentional dimensions (Faems et al., 2008; Nooteboom, 1996). Competence engenders positive expectations about partner firms' ability to perform in line with existing agreements; intentional or goodwill trust instead refers to exchange partners' intentions to avoid opportunistic behavior. The present study adopts 
Zaheer et al.'s (1998) conceptualization of trust and posits that the existing level of trust that the focal firm in general has in its business partner firms facilitates exchange relationships (McEvily, Perrone, and Zaheer, 2003; Rousseau, Sitkin, Burt, and Camerer, 1998; Zaheer et al., 1998). Gaur et al. (2011) have used a similar conceptualization of trust between a focal firm and its business partners. Trust produces organizationally valued outcomes, such as reduced transaction costs and enhanced organizational performance (Adobor, 2005; Lee and Cavusgil, 2006; Luo, 2008).

Relational capital and social network perspectives indicate that a firm's ability to establish new alliances also depends on network structures (Beckman et al., 2004; Mitsuhashi and Greve, 2009). Extending this argument, a firm's existing level of trust in business partners may encourage future alliances: Trust enables firms to solve mutual problems and conflicts that arise during the alliance; in this sense "trust stands out as one of the internal conditions that appear particularly critical at the onset of strategic alliances" (Koljatic and Silva, 2008: 649). Indeed, Luo (2008) argues that the level of trust a particular firm has in existing business partners and suppliers affects the likelihood of alliance formation.

Social capital gained from the existing level of trust can also enhance firm confidence and increase the chances of future alliance creation. Trust embedded in organizational norms and routines becomes a guiding factor for alliance formation behavior. It provides assurance to the focal firm that the potential alliance partner will not take advantage of its vulnerability even if such opportunities exist (Chaturvedi and Gaur, 2009). Thus, a greater level of existing trust may allow focal firms to avoid the drafting of rigid and complex contracts which are inherently expensive. In addition, trust-based relationships enrich the knowledge base of the focal firm for managing collaborative relationships with more efficiency and effectiveness. Potential partners 
can form the alliance more easily if the focal firm already has trust-based relationships with existing partners. Information regarding the trustworthiness of an exchange partner should alleviate the potential threat of opportunism and lower transaction costs and uncertainties associated with extensive partner searches. Accordingly, the existing level of trust should encourage alliance formation by the focal firm.

H3: An SME's existing level of trust in business partners relates positively to the likelihood of alliance formation.

\subsection{Trust as a moderator}

Collaborative relationships, such as R\&D strategic alliances, require a balance between protecting the firm's proprietary assets and establishing trust with an exchange partner (Hagedoorn, 2002). The R\&D alliances likely involve mutual transfers of strategic information and sensitive technological knowledge but relatively weak incentives to prevent leakage (Das and Teng, 2002). Although managers can mitigate the risk of misappropriation by structuring each partner firm's payoffs according to alliance outcomes (Kogut, 1988), relational risk may dissipate the firm's competitive advantage (Bleeke and Ernst, 1995). Consequently, trust of the focal firm in its business partners in general can act as a safeguarding mechanism and mitigate uncertainties associated with future displays of opportunism (Dyer and Singh, 1998).

\subsubsection{Moderating effect of trust on environmental uncertainty-alliance formation} relationship. Environmental uncertainty may discourage R\&D alliance formation in SMEs for two reasons: First, in uncertain conditions, managers choose not to overburden themselves with more information processing demands. Second, when environmental uncertainty rises, SMEs do not find the unforeseen contingencies associated with $R \& D$ alliances attractive enough to establish long-term partnerships. Trust can alleviate both concerns: SMEs with more trust in existing business partners agree to rely on those partners somewhat "blindly" and form alliances 
(Krishnan et al., 2006). Rapid information processing demands decrease, because trust offers an assurance of reduced opportunistic behaviors (McEvily et al., 2003).

Similarly, trust allows for greater flexibility in responding to changing environmental conditions, facilitates investments in relation-specific assets, and reduces transaction costs associated with costly monitoring and other formal safeguarding mechanisms (Dyer and Chu, 2003; Nooteboom, Berger, and Noorderhaven, 1997). In terms of enhanced exchange value, trust mobilizes parties to share more knowledge and pursue relational governance mechanisms that substitute for costly contracts (Lee and Cavusgil, 2006; McEvily et al., 2003). With external uncertainty, trust motivates actors to collaborate fully and integrate activities in a way that effectively coordinates the task and resource interdependencies associated with an economic exchange relationship. Trust may also motivate partners to engage in value-creation initiatives that are difficult to specify explicitly in a contract. Thus, a high level of trust in the partner firm makes alliance formation rational. An SME with high level of trust should perceive that an alliance partner will maintain salient promises and commitment. Accordingly,

H4: The level of trust the focal firm has in business partner firms attenuates the negative effect of environmental uncertainty on alliance formation.

3.4.2. Moderating effect of trust on knowledge intensity-alliance formation relationship. The presence of trust orientation in exchange relationships lead to more accurate and timely information exchange (Nooteboom et al., 1997), which may help the focal firm better understand business partners. The focal firm's trust in its partner firms reduces transaction costs at different stages of a transaction, thereby enhancing the likelihood of collaborative behavior. For example, in a trust-based relationship, partners often draft flexible contracts to accommodate ex post contingencies and deviations, which reduce the costs of drafting a complex contract. Moorman, Zaltman, and Deshpande (1992) report that trust enables entities to find fruitful solutions to 
conflicts and facilitates problem solving. Such an approach also reduces transaction costs related to expensive negotiations and extensive partner monitoring (Dyer and Chu, 2003; Dyer and Singh, 1998; McEvily et al., 2003).

Although SMEs with knowledge-intensive production outputs should avoid R\&D alliances, for fear of opportunistic behaviors by alliance partners, extant findings in trust-related research suggest that trust can mitigate the threat of perceived opportunism. An SME with an overall trust orientation may be less concerned about exploitation by potential alliance partners. Forming alliances with others may enhance an SME's legitimacy, and the prevalence of trust orientation may encourage firms to form alliances. Thus,

H5: The level of trust the focal firm has in business partner firms attenuates the negative effect of knowledge intensity on alliance formation.

\section{Methods}

\subsection{Sample}

The empirical tests involve a sample of SMEs in Germany. This sample provides a useful alternative to extant research, which relies mostly on large enterprises from the United States and United Kingdom. In addition, constructs such as trust and uncertainty should affect these resource-poor SMEs more than they do larger firms.

The sample identification relied on two criteria: (1) firm turnover should not be more than one billion Euros, and (2) the firm should not be listed on any stock exchange. The Institut für Mittelstandsforschung Bonn notes approximately 100,000 manufacturing firms in Germany. Of these, approximately 8,000 are listed, and 90\% of the remaining firms are micro- and very small enterprises, with fewer than 10 full-time employees. These exclusions leave a population of approximately 10,000 SMEs. Addresses were available for nearly $40 \%(3,978)$ of these SMEs, which provides a good representation of the population of SMEs in Germany. 


\subsection{Data collection}

Questionnaires addressed to CEOs and top management team members were administered twice, in September 2004 and June 2007. The first survey consisted of three rounds and produced 705 completed questionnaires, with information on alliance formation during 1999-2003. The removal of questionnaires with missing information on key variables left a final sample of 565 questionnaires, for a $14.2 \%$ response rate, comparable to alliance-related surveys in other countries (e.g., 14.4\% in China, Isobe, Makino, and Montgomery, 2000; 18\% in India, Krishnan et al., 2006). The second survey round, three years later, again solicited the firms that responded in the first round (705). After one reminder, 308 completed questionnaires arrived over two months. After discarding 10 partially completed questionnaires, the final sample consisted of 298 firms that provided alliance formation data for 2004-2006. The combination of the two surveys provided longitudinal data on alliance formation and other firm characteristics for eight years (1999-2006).

The tests for response bias followed the procedure suggested by Oppenheim (1966) and compared responses received in early and late rounds. The t-tests indicated no significant differences between early and late respondents in either survey round. In addition, a comparison of the industry composition of the respondents to the 2007 survey with that of nonrespondents from the 2003 survey revealed no differences in the industrial makeup of the respondents, which offered a reasonable assurance against nonresponse bias. ${ }^{2}$

\subsection{Dependent variable}

To measure the incidence of a new alliance formation, respondents listed the number of new alliances they formed in each of the eight years of the study period. These alliances might

\footnotetext{
${ }^{2}$ A more appropriate test of nonresponse bias would compare respondents and nonrespondents on key characteristics. However, this test was impossible, due to the lack of data on SMEs in secondary sources.
} 
include various interfirm linkages, such as licensing and distribution arrangements or joint ventures. Most firms undertook only one alliance per year, so the dependent variable is a dichotomous variable, equal to one if the firm forms an alliance in a given year, and zero otherwise.

\subsection{Explanatory variables}

Knowledge intensity, environmental uncertainty, and trust are the key explanatory variables. Knowledge intensity relates to a firm's use of technical skills during the production process, traditionally measured with proxies such as R\&D expenditures and number of firm patents. However, these measures are less appropriate for SMEs (Eisenhardt and Schoonhoven, 1990; Spender and Grant, 1996), which rarely have distinct R\&D departments and engage less in patenting; the number of patents an SME holds likely reflects a strategic positioning rather than knowledge intensity (Eisenhardt and Schoonhoven, 1990). Therefore, a better measure of knowledge intensity in SMEs relies on managerial assessments (Eisenhardt and Schoonhoven, 1990). Four items, with a seven-point Likert scale, measure knowledge intensity.

Environmental uncertainty consists of environmental dynamism and environmental complexity. In line with extant research, unpredictable changes emanating from competitive, market, and technological environments represent the pertinent sources of uncertainty for the sample firms (Gaur et al., 2011; Dias and Magrico, 2011). The related three-item measure of environmental uncertainty follows definitions proposed by Duncan (1972), Milliken (1987) and Galbraith (1973). Finally, the measure of interorganizational trust comes from Gaur et al. (2011). The survey instrument appears in Appendix A.

\subsection{Control variables}

The control variables include firm size, age, capital structure, $R \& D$ intensity, advertising 
intensity, and prior performance. Firm size equals the natural logarithm of total sales. Age is the number of years since the firm's inception to the year of observation. Both firm size and age can influence alliance formation activities (Wassmer, 2010). The control for the capital structure of the firm uses the debt-to-equity ratio, which suggests the availability of slack resources owned by the firm (Bühner, 1987) and influences the firm's decision to enter into alliances. For R\&D intensity, the measure uses the ratio of $R \& D$ expenditures to total sales; advertising intensity is the ratio of marketing expenditures to total sales. Because alliance formation aims to gain access to intangible assets (Wassmer, 2010), it is important to control for the intangible asset base of a firm, as represented by R\&D and advertising intensities. Finally, prior performance, as measured by return on assets, controls for the organizational slack that firms may use to acquire resources in the external market rather than through alliances.

\section{Results}

\subsection{Measurement properties}

The evaluation of the convergent and discriminant validity of the measures relies on a confirmatory factor analysis (CFA) with AMOS 16.0. The theoretical constructs in the CFAtrust, uncertainty, and knowledge intensity — appeared in a larger survey. The test of overall model fit used maximum likelihood; the latent variables should correlate with each other. The chi-square statistic often is sensitive to a large sample size, but the CFA results of the measurement model in Table 1 indicate excellent fit with the data $\left(\chi_{41}^{2}=151.14\right.$, root mean square error of approximation $[\mathrm{RMSEA}]=.056$, goodness-of-fit index $[\mathrm{GFI}]=.96$, adjusted goodness-of-fit index $[\mathrm{AGFI}]=.95$, normed fit index $[\mathrm{NFI}]=.92$, confirmatory fit index $[\mathrm{CFI}]=$ .94) (Gefen, Straub, and Boudreau, 2000; Hu and Bentler, 1999). The results in Table 1 also indicate that several combinations of constrained models do not fit the data well. 
Insert Table 1 about here

The results in Table 2 indicate further support for the convergent validity of the measures. Each factor loading is greater than twice the standard error (Anderson and Gerbing, 1988), which implies that each loading is significant at $p=.01$ (Gefen et al., 2000). The lowest ratio of loading to standard error is 8.31 (Table 2). All factor loadings are significant at $p=.001$. The composite factor reliability values, which assess the internal consistency of a measure, vary from .64 to .74 . These findings offer robust support for the convergent validity of the items in each scale.

Insert Table 2 about here

Three methods serve to test the discriminant validity of the measures. First, all intercorrelations between the latent variables, except trust and knowledge intensity (.68), are less than .60 (Table 3). Second, the average variance extracted values, which measure the amount of variance captured by a construct compared with variance due to random measurement error, are less than the .50 limit (Fornell and Larcker, 1981), as Table 2 shows.

Insert Table 3 about here

Third, a constrained analysis sets the correlation of one pair of variables (e.g., trust and knowledge intensity) to 1.0 and tests the model fit again. According to Anderson and Gerbing (1988), the constructs are theoretically different (i.e., discriminant validity) when a chi-square difference test indicates support for the original model. The different chi-square values and various fit indices for the constrained models in Table 1 indicate that the model fit statistics of 
the original three-factor model are significantly better than those of the constrained models, in strong support of discriminant validity and the unidimensionality of the measurement scales.

\subsection{Hypotheses testing}

The reliable and valid scales support the development of composite factor scores for the three variables from the principal component analysis. Factor scores, with a mean of zero and standard deviation of one, are preferable to averaged scores, because the different factors can be orthogonal, which reduces the problem of multicollinearity. Table 4 presents the descriptive statistics and correlations. The average number of alliances is .12, which suggests that 439 firms undertook alliances during 1999-2006. The formal test of multicollinearity used the variance inflation factor statistic; the highest value was 2.26 , too low for any multicollinearity concerns.

Insert Table 4 about here

For the test of the theoretical model, panel data logit estimation involves building the models in a hierarchical manner, to ensure the results remain stable. Model 1 features all the control variables; Model 2 contains the three main effect hypotheses; Models 3 and 4 accept the interaction effects one by one; and Model 5 includes all hypothesized effects. Table 5 presents the results of the panel data estimation.

Insert Table 5 about here

In support of H1, perceived environmental uncertainty relates negatively to the likelihood of alliance formation; the beta coefficient for environmental uncertainty is negative and significant (Model 2: $\beta=-2.038, \mathrm{t}<.001$ ). However, the beta coefficient for knowledge intensity is not significant, suggesting that knowledge intensity does not relate negatively to a firm's 
alliance formation likelihood; $\mathrm{H} 2$ is not supported. . In line with $\mathrm{H} 3$, which predicts that interorganizational trust increases the likelihood of alliance formation, the beta coefficient of trust is positive and significant (Model 2: $\beta=1.685, \mathrm{t}<.001$ ). The signs and significance of these hypothesized effects remain the same across different models.

In Models 3 and 4, the addition of the interaction terms significantly improves model fit; the significance of interaction terms thus is not a spurious relationship. Although $\mathrm{H} 4$ predicts that trust attenuates the negative effect of environmental uncertainty on alliance formation likelihood, the beta coefficient of the interaction between environmental uncertainty and trust is negative and significant $(\beta=-.643, p<.001)$, so $\mathrm{H} 4$ receives no support. Finally, H5 predicts that trust attenuates the negative effect of knowledge intensity on the likelihood of alliance formation. The beta coefficient for the interaction between knowledge intensity and trust is positive and significant $(\beta=.368, p<.01)$. Despite the lack of a significant direct effect of knowledge intensity, the significant interaction effect suggests that firms with high degrees of knowledge intensity are more likely to form alliances if the level of trust in business partners is high, in support of H5.

\section{Discussion and implications}

This study attempts to enhance understanding of alliance formation by focusing on firmlevel (knowledge intensity, trust) and environmental (environmental uncertainty) determinants. Thus the study addresses two research questions: (1) To what extent do external and internal factors affect SME alliance formation? and (2) How does existing level of interpartner trust influence the relationship of production knowledge intensity, environmental uncertainty, and alliance formation? The empirical analyses indicate that environmental uncertainty has a negative, significant impact on SME alliance formation, but interfirm trust encourages such 
collaborative designs. Contrary to expectations, trust has no moderating impact on the environmental uncertainty-alliance formation relationship. In addition, no evidence emerges of constraining influences of knowledge intensity on SME alliance formation. However, interfirm trust positively interacts with knowledge intensity to predict alliance formation.

\subsection{Research implications}

This study adds to the nuanced understanding of the relationships among interpartner trust, knowledge intensity, environmental uncertainty, and alliance formation. First, the present work contributes to the alliance literature by identifying environmental uncertainty and production process knowledge intensity as possible deterrents to SME alliance formation. Second, interpartner trust is a precursor of SME alliance formation, in line with theory that identifies prior ties and partner social capital as attractive partner attributes during alliance partner selection (Beckman et al., 2004). Third, this study finds that trust can alleviate concerns of potential misappropriation by partners in knowledge-intensive exchanges. However, trust cannot offset concerns related to the unpredictability of the external environment. This finding corroborates the view that external uncertainty may not be managed by relational governance (Beckman et al., 2004). However, the threat of behavioral uncertainty gets mitigated by higher levels of trust, which alleviate apprehensions of opportunism. These findings suggest that environmental and behavioral uncertainty have differential impacts on SMEs' strategic choices.

This discussion requires consideration of the finding of the negative relationship between environmental uncertainty and alliance formation likelihood in SMEs, which contradicts the theoretical tenets of resource dependence theory (Pfeffer and Salancick, 1978) and results of some other related studies (e.g., Marino et al., 2008). Resource dependence theory specifies that firms rely on alliances to obtain complementary resources and power when faced with greater 
environmental uncertainty. However, this article subscribes to the view that SMEs seek more control in the face of increased uncertainty and avoid alliance formation which may reduce their flexibility (Williamson, 1985, 1991). This is in line with recent findings that firms prefer greater flexibility under conditions of higher external uncertainty. For example, Ning, Boulding, and Staelin (2010) observe that firms choose non-equity alliances over joint ventures when external uncertainty increases as the former indicates greater flexibility. Applying the same logic the findings of this study suggests that when faced with increased uncertainty SMEs may emphasize external conditions and prefer their standalone status which provides greater flexibility. However, it should be noted that the findings also might reflect the high degree of uncertainty avoidance that marks German culture (Hofstede, 1980).

Another interpretation of the negative effect of environmental uncertainty on alliance formation likelihood might turn to Milliken's (1987) conceptualization of three types of environmental uncertainty: state, effect, and response uncertainty. State uncertainty arises when managers fail to predict how environmental components will change; for this study context, perhaps environmental dynamism deters German SMEs from entering alliances. Effect uncertainty occurs when managers cannot predict whether or how a specific change may influence their organizations. Finally, response uncertainty refers to a lack of knowledge about the response alternatives or consequences of an environmental change. Managers in an SME may not always know what strategy is possible in response to an environmental change or what effect an environmental change will have on organizations. Thus SMEs facing higher levels of uncertainty may avoid forming alliances.

The finding with regard to the negative relationship between knowledge intensity and alliance formation is also noteworthy in the context of the SMEs. This result implies that 
knowledge intensive SMEs are less likely to form strategic alliances as such firms are more apprehensive about the possible misappropriation of their knowledge assets. This is in tune with the transaction cost perspective which emphasizes the importance of opportunism in exchange relationships. This particular finding also makes sense from a resource dependence slant as it indicates more knowledge intensive SMEs are simply less resource constrained and therefore are less reliant on alliance formation.

Finally, this study provides an opportunity to test arguments from multiple perspectives. Organizational scholars call for international views on strategy and SME research that test extant theories and perspectives in non-U.S. contexts (Gaur et al., 2011; Singh, Gaur, and Schmid, 2010). Accordingly, this research contributes meaningfully to strategy literature by drawing fresh attention to alliance research in general and the factors that facilitate or impede alliance formation in particular.

\subsection{Managerial implications}

The research findings have important managerial implications for both focal firms and business partners. Top managers of partner organizations should develop and maintain strong trust-based relationships to alleviate concerns of opportunism, especially pertaining to strategic knowledge. Ideally, organizations assist each other in moving from a formal contractual relationship to a more relational form of governance, in the interest of joint value creation. Managers should understand that uncertainty arising from the external environment may have a detrimental effect on alliance formation. Thus, managers of the SMEs need to scan the environment continuously and devise strategies to mitigate potentially negative impacts. Appropriate measures such as proactive environmental scanning, planning, or proactive networking endeavors may prevent such negative effects. The findings also imply that in 
conditions of higher internal uncertainty, faced with knowledge-leakage concerns, managers should continue relying on trust-based governance while managing R\&D alliances.

\section{Limitations and further research}

The results of this study should be interpreted with appropriate caution. First, this analysis only surveys German SMEs in the manufacturing industry. Additional studies should extend the research to other countries, larger companies, and service industries. Second, the data collection did not provide details on alliance types. Further studies could examine how the antecedents or reasoning underlying alliances vary depending on the nature and structure of the alliances. For example, equity-based alliances may alleviate concerns related to opportunistic behavior by creating "mutual hostage" situations (Steensma, Marino, Weaver, and Dickson, 2000). There is a rich body of literature examining the governance structure of alliance relationships; exploring the antecedents of alliance governance structure is beyond the scope of this research.

Third, the data collection used a key informant survey methodology, which raises concerns about common method bias. However, published sources of financial information on SMEs are not readily available. Fourth, though this study notes three important factors that affect alliance formation, other factors — such as organizational resources, capabilities, environmental munificence, current strategy, or previous alliance experience_also could influence SME alliance formation. Unfortunately, this study could not examine these factors due to the limitation of the data. The quality of previous alliance experience, in particular, has been found to be important predictor of alliance formation. We have very few firms in our sample which enter into more than one alliance during the study time period. An indicator variable to control for firms that have more than one alliance is not significant in the regression models. A 
meaningful extension of this research would investigate other firm-level and external factors that may play important roles for alliance formation by SMEs.

In conclusion, alliance formation depends partially on factors related to the external environment, transaction characteristics, and relational characteristics. This study integrates the relational perspective with transaction cost economics, applied to the context of R\&D alliance relationships. This study sets the stage for further empirical research relating to alliance formation, involving other internal and external variables in different research settings. 


\section{References}

Adobor H. Trust as sensemaking: The microdynamics of trust in interfirm alliances. J Bus Res 2005; 58 (3): 330-37.

Ahuja G. The duality of collaboration: Inducements and opportunities in the formation of interfirm linkages. Strateg Manage J 2000; 21: 317-43.

Anderson JC, Gerbing DW. Structural equation modeling in practice: a review and recommended two-step approach. Psych Bull 1988; 103: 411- 23.

Ariño A. Measures of strategic alliance performance: an analysis of construct validity. J Int Bus Stud 2003; 34: 66-79.

Autio E, Sapienza HJ, Almeida JG. Effects of age at entry, knowledge intensity, and imitability on international growth. Acad Manage J 2000; 43: 909-24.

Beckman CM, Haunschild PR, Phillips DJ. Friends or strangers? firm-specific uncertainty, market uncertainty, and network partner selection. Organ Sci 2004; 15: 259-275.

Bleeke J, Ernst D. Is your strategic alliance really a sale? Harvard Bus Rev 1995; 73(1):97- 105.

Buhner, R. Assessing international diversification of West German corporations, Strateg Manage J, 1987; 8: 25-37.

Chaturvedi, S. \& Gaur, A. S. 2009. A dynamic model of trust and commitment development in strategic alliances. IIM B Manage Rev, 21 (3): 173-188.

Chen H, Chen TJ. Governance structure in strategic alliances: transaction cost versus resourcebased perspective. J World Bus 2003; 38: 1-14.

Chi T. Trading in strategic resources: necessary conditions, transaction cost problems, and choice of exchange structures. Strateg Manage J 1994; 15(4):271- 90.

Chung SA, Singh H, Lee K. Complementarity, status similarity, and social capital as drivers of alliance formation. Strateg Manage J 2000; 21: 1-22.

Conner KR, Prahalad CK. A resource-based theory of the firm: knowledge versus opportunism. Organ Sci 1996; 7: 477-501.

Das TK, Teng BS. The dynamics of alliance conditions in the alliance development process. $\mathrm{J}$ Manage Stud 2002; 39: 725-46.

Dess GG, Beard DW. Dimensions of organizational task environments. Adm Sci Q 1984; 29: $52-73$.

Dias, J, Magrico, MV. The impact of resource conditions and environmental uncertainty on inter-firm alliance strategies. App Econ 2011; 43: 757-65.

Dickson PH, Weaver KM. Environmental determinants and individual-level moderators of alliance use. Acad Manage J 1997; 40: 404-25.

Dollinger, M., Golden, P. Interorganizational and collective strategies in small firms: Environmental effects and performance. J of Manage 1992 18: 695-715.

Doz Y, Hamel G. Alliance advantage: the art of creating value through partnering. Boston, MA: Harvard Business School Press; 1998.

Dyer JH, Singh H. The relational view: cooperative strategy and sources of interorganizational competitive advantage. Acad Manage Rev 1998; 23: 660-79.

Duncan RG. Characteristics of organizational environments and perceived environmental uncertainty. Adm Sci Q 1972; 17: 313-27.

Dyer $\mathrm{JH}$, Chu W. The role of trustworthiness in reducing transaction costs and improving performance: empirical evidence from the United States, Japan, and Korea. Organ Sci 2003; 14: $57-68$. 
Eisenhardt KM, Schoonhoven GB. Organizational growth: linking founding team, strategy, environment, and growth among U.S. semiconductor ventures, 1978-1988. Adm Sci Q 1990; 35: 504-29.

Faems D, Janssens M, Madhok A, Van Looy B. Toward an integrative perspective on alliance governance: connecting contract design, trust dynamics, and contract application, Acad Manage J 2008; 51: 1053-78.

Fornell C, Larcker DF. Evaluating structural equation models with unobservable variables and measurement error. J Mark Res 1981; 18: 39-50.

Galbraith J. Designing Complex Organizations. Addison-Wesley: Reading, MA; 1973.

Gaur, AS., Mukherjee, D., Gaur, SS., \& Schmid, F. 2011. Environmental and firm level influences on inter-organization trust and SME performance. J Manage Stud, 48(8): 1752-1781.

Gefen D, Straub DW. Boudreau MC. Structural equation modeling and regression: guidelines for research practice. Communications of the Association for Information Systems 2000; 4: 176.

Ghoshal S, P Moran. Bad for practice: a critique of the transaction cost theory, Acad Manage Rev 1996; 21: 13-48.

Grant RM. Toward a knowledge-based theory of the firm. Strateg Manage J 1996; 17: 109-22.

Gulati R. Network location and learning: the influence of network resources and firm capabilities on alliance formation. Strateg Manage J 1999; 20: 397-420.

Gulati R, Gargiulo M. Where do interorganizational networks come from? Am J Soc 1999; 104: 1439-93.

Gulati R., Nickerson, J. A. Interorganizational trust, governance choice, and exchange performance. Org Sci 2008; 19: 688-708.

Hamel G. Competition for competence and interpartner learning within international strategic alliances. Strateg Manage J 1991; 12: 83-103.

Hagedoorn J. Inter-firm R\&D partnerships: an overview of major trends and patterns since 1960. Res Policy 2002; 31: 477-92.

Hofstede, G.H. Culture consequences: international differences in work-related values, Sage Publications, London, 1980.

Hrebiniak LG, Joyce WF. Organizational adaptation: strategic choice and environmental determinism. Adm Sci Q 1985; 30: 336-50.

$\mathrm{Hu}$ L, Bentler PM. Cutoff criteria for fit indexes in covariance structure analysis: conventional criteria versus new alternatives. Structural Equation Modeling 1999; 6: 1-55.

Isobe, T., Makino, S., Montgomery, D. B. Resource commitment, entry timing and market performance of foreign direct investments in emerging economies: The case of Japanese international joint ventures in China. Acad of Manage J 2000; 43: 468-84.

Johnson JL, Sohi RS. The development of interfirm partnering competence: platforms for learning, learning activities, and consequences of learning. J Bus Res 2003;56(9):757-66.

Kale, P., H. Singh. Managing strategic alliances: What do we know now, and where do we go from here? Acad Manage P 2009; 23(3): 45-62.

Kale P, Singh H, Perlmutter H. Learning and protection of proprietary assets in strategic alliances: building relational capital. Strateg Manage J 2000; 21: 217-37.

Kogut B. Joint ventures: Theoretical and empirical perspectives. Strateg Manage J 1988; 9: 31932.

Kogut B. Joint ventures and the option to expand and acquire. Manage Sci 1991; 37:19- 33.

Krishnan R, Martin X, Noorderhaven NG. When does trust matter to alliance performance? Acad 
Manage J 2006; 49: 894-917.

Koza M, Lewin A. The co-evolution of strategic alliances. Organ Sci 1998; 9: 255-64.

Lai W-H, Chang, P-L. Corporate motivation and performance in R\&D alliances. J Bus Res 2010; 63: 490-96.

Lavie, D. Alliance portfolios and firm performance: A study of value creation and appropriation in the U. S. software industry. Strateg Manage J 2007; 28: 1187-1212.

Lavie D, Rosenkopf L. Balancing exploration and exploitation in alliance formation. Acad Manage J 2006; 49: 797-818.

Lavie D, Lechner C, Singh H. The performance implications of timing of entry and involvement in multipartner alliances. Acad Manage J 2007; 50: 578-604.

Lee CW. Strategic alliances influence on small and medium firm performance. J Bus Res 2007; 60:731-41.

Lee Y, Cavusgil TS. Enhancing alliance performance: the effects of contractual-based versus relational-based governance. J Bus Res 2006; 59: 896-905.

Li, D. Eden, L., Hitt, M. A., Ireland, R. D. Friends, acquaintances, or strangers? partner selection in R\&D alliances. Acad of Manage J 2008; 315-334.

Lohrke FT, Kreiser PM, Weaver KM. The influence of current firm performance on future SME alliance formation intentions: a six-country study. J Bus Res 2006; 59(1): 19-27.

Luo, Y. Are joint venture partners more opportunistic in a more volatile environment? Strateg Manage J 2007; 28(1): 39-61.

Luo Y. Structuring interorganizational cooperation: the role of economic integration in strategic alliances. Strateg Manage J 2008; 29: 617-37.

Marino LD, Lohrke FT, Hill JA, Weaver KM, Tambunan T. Environmental shocks and SME alliance formation intentions in an emerging economy: evidence from the Asian financial crisis in Indonesia. Ent Theo and Pract 2008; 32: 157-84.

McEvily B, V Perrone, A Zaheer. Trust as an organizing principle. Organ Sci 2003; 14(1): 91103.

Milliken FJ. Three types of perceived uncertainty about the environment: state, effect, and response uncertainty. Acad Manage Rev 1987; 12: 133-43.

Mitsuhashi $\mathrm{H}$, Greve H. A matching theory of alliance formation and organizational success: complementarity and compatibility. Acad Manage J 2009; 52: 975-95.

Moorman C, G Zaltman, R Deshpande. Relationships between providers and users of market research: the dynamics of trust within and between organizations, J Mark Res 1992; 29 (3): 314-28.

Ning, L., Boulding, W, Staelin, R. General alliance experience, uncertainty, and marketing alliance governance mode choice, J of the Acad Mark Sci 2010; 38: 141-158.

Nohria N, Garcia-Pont C. Global strategic linkages and industry structure. Strateg Manage J 1991; 12: 105-24.

Nooteboom, B. Trust, opportunism and governance: a process and control model. Org Stud 1996; 17 (6): 985-1010.

Nooteboom B, Berger H, Noorderhaven N. Effects of trust and governance on relational risk. Acad Manage J 1997; 40: 308-38.

Oppenheim AN. Questionnaire Design and Attitude Measurement. New York: Basic Books; 1966.

Parkhe, A. Strategic alliance structuring, a game theoretic and transaction cost examination of interfirm cooperation. Acad Manag J 1993; 36: 794 - 829. 
Park SH, Chen R, Gallagher S. Firm resources as moderators of the relationship between market growth and strategic alliances in semiconductor start-ups. Acad Manage J 2002; 45: 527-50.

Park SH, Russo M. When competition eclipses cooperation: an event history analysis of alliance failure. Manage Sci 1996; 42: 875-90.

Park SH, Zhou D. Firm heterogeneity and competitive dynamics in alliance formation. Acad Manage Rev 2005; 36: 531-34.

Pfeffer, J. Salancik, G. R. The external control of organizations 1978; New York: Harper Row.

Pisano GP. The R\&D boundaries of the firm: an empirical analysis. Adm Sci Q 1990; 35: $153-$ 76.

Podolny JM. Market uncertainty and the social character of economic exchange. Adm Sci Q 1994; 39: 458-483.

Rothermael FT, Boeker W. Old technology meets new technology: complementarities, similarities, and alliance formation. Strateg Manage J 2008; 29: 47-77.

Rousseau DM, Sitkin SB, Burt RS, Camerer C. Not so different after all: a cross-discipline view of trust. Acad Manage Rev 1998; 23: 393-404.

Sampson RC. Organizational choice in R\&D alliances: Knowledge-based and transaction cost perspectives. Man Dec Econ 2004; 25: 421-36.

Singh, D. A., Gaur, A. S., Schmid, F. Corporate diversification, TMT experience and performance: evidence from German SMEs. Manage Int Rev 2010; 50 (1): 35-56.

Spender JC, Grant RM. Knowledge and the firm: overview. Strateg Manage J 1996; 17: 5-9.

Steensma, H., Marino, L., Weaver, M., Dickson, P. The influence of national culture on the formation of technology alliances by entrepreneurial firms. Acad Manage J 2000; 43: 951974.

Steensma HK, Corley KG. Organizational context as a moderator of theories on firm boundaries for technology sourcing. Acad Manage J 2001; 44: 271-91.

Subramani MR, Venkatraman N. Safeguarding investments in asymmetric interorganizational relationships: theory and evidence. Acad Manage J 2003; 46: 46-62.

Sutcliffe, K. M. Zaheer, A. Uncertainty in the transaction environment: an empirical test. Strateg Manage J 1998; 19: 1-23.

Teng BS. Corporate entrepreneurship activities through strategic alliances: a resource-based approach toward competitive advantage. J Manage Stud 2007; 44:119-42.

Tushman M, Nadler D. Information processing as an integrating concept in organizational design. Acad Manage Rev 1978; 3: 613-24.

Walker G, Weber D. Supplier competition, uncertainty, and make-or-buy decisions. Acad Manage J 1987; 30: 589-96.

Wassmer, U. Alliance portfolio: a review and research agenda," J of Manage 2010; 36(1):14171.

Williamson, O.E. The Economic Institutions of Capitalism. New York: The Free Press 1985.

Williamson, O.E. Comparative economic organization: the analysis of discrete structural alternatives. Adm Sci Q 1991; 36: 269-296.

Ybarra EC, Turk T. The evolution of trust in information technology alliances. J High Technol Managem Res 2009; 20: 62-74.

Zaheer A, McEvily B, Perrone V. Does trust matter? exploring the effect of interorganizational and interpersonal trust on performance. Organ Sci 1998; 9: 14-159. 
Table 1. Fit indices, CFA model

\begin{tabular}{lcccccccc}
\hline Model & $\chi^{2}$ (d.f.) & RMR & RMSEA & GFI & AGFI & NFI & TLI & CFI \\
\hline Hypothesized Model & $\begin{array}{c}151.14 \\
(41)\end{array}$ & .076 & .056 & .969 & .951 & .924 & .924 & .943 \\
$\begin{array}{l}\text { Constrained Model 2 (trust and } \\
\text { knowledge intensity) }\end{array}$ & $\begin{array}{c}259.95 \\
(42)\end{array}$ & .288 & .078 & .951 & .923 & .870 & .853 & .888 \\
$\begin{array}{l}\text { Constrained Model 3 (trust and } \\
\text { environmental uncertainty) }\end{array}$ & $\begin{array}{c}679.50 \\
(42)\end{array}$ & .499 & .133 & .895 & .836 & .660 & .570 & .672 \\
$\begin{array}{l}\text { Constrained Model 4 (knowledge } \\
\text { Intensity and environmental } \\
\text { uncertainty) }\end{array}$ & $\begin{array}{c}738.19 \\
(42)\end{array}$ & .529 & .139 & .901 & .844 & .631 & .531 & .642 \\
\hline
\end{tabular}

Table 2. Measurement properties

\begin{tabular}{|c|c|c|c|c|c|c|c|c|}
\hline Construct & Items & $\begin{array}{l}\text { Unstandardized } \\
\text { Loading }\end{array}$ & SE & $\begin{array}{l}\text { Standardized } \\
\text { Loading }\end{array}$ & $\begin{array}{c}\text { Item } \\
\text { Reliability }\end{array}$ & $\begin{array}{c}\text { Composite } \\
\text { Factor } \\
\text { Reliability }\end{array}$ & $\begin{array}{l}\text { Cronbach's } \\
\text { Alpha }\end{array}$ & $\begin{array}{l}\text { Average } \\
\text { Variance } \\
\text { Extracted }\end{array}$ \\
\hline \multirow{4}{*}{ Trust } & $\begin{array}{l}\text { Trust } \\
1\end{array}$ & 1.031 & 0.124 & 0.413 & 0.171 & \multirow{4}{*}{0.644} & \multirow{4}{*}{0.642} & \multirow{4}{*}{0.321} \\
\hline & $\begin{array}{l}\text { Trust } \\
2\end{array}$ & 1.161 & 0.121 & 0.461 & 0.213 & & & \\
\hline & $\begin{array}{l}\text { Trust } \\
3\end{array}$ & 1.328 & 0.138 & 0.655 & 0.429 & & & \\
\hline & $\begin{array}{l}\text { Trust } \\
4\end{array}$ & -- & & 0.687 & 0.472 & & & \\
\hline \multirow{4}{*}{$\begin{array}{l}\text { Knowledge } \\
\text { Intensity }\end{array}$} & KI1 & 0.906 & 0.079 & 0.548 & 0.300 & \multirow{4}{*}{0.667} & \multirow{4}{*}{0.667} & \multirow{4}{*}{0.334} \\
\hline & $\mathrm{KI} 2$ & 0.904 & 0.077 & 0.595 & 0.354 & & & \\
\hline & $\mathrm{KI} 3$ & 0.975 & 0.081 & 0.567 & 0.321 & & & \\
\hline & $\mathrm{KI} 4$ & -- & & 0.599 & 0.359 & & & \\
\hline \multirow{3}{*}{$\begin{array}{l}\text { Environmental } \\
\text { Uncertainty }\end{array}$} & EU1 & 0.879 & 0.053 & 0.739 & 0.546 & \multirow{3}{*}{0.739} & \multirow{3}{*}{0.723} & \multirow{3}{*}{0.492} \\
\hline & EU2 & 0.664 & 0.049 & 0.541 & 0.293 & & & \\
\hline & EU3 & -- & & 0.799 & 0.638 & & & \\
\hline
\end{tabular}

Table 3. Interfactor correlation coefficients

\begin{tabular}{lclc}
\hline Items & & & Estimate \\
\hline Trust & $<->$ & Knowledge Intensity & .683 \\
Trust & $<->$ & Environmental Uncertainty & -.500 \\
Knowledge Intensity & $<->$ & Environmental Uncertainty & -.578 \\
\hline
\end{tabular}


Table 4. Descriptive statistics and correlations ${ }^{a}$

\begin{tabular}{|c|c|c|c|c|c|c|c|c|c|c|c|c|}
\hline Variables & Mean & $\begin{array}{l}\text { Standard } \\
\text { Deviation }\end{array}$ & 1 & 2 & 3 & 4 & 5 & 6 & 7 & 8 & 9 & 10 \\
\hline 1. Alliance formation (=1) & 0.12 & 0.32 & -- & & & & & & & & & \\
\hline 2. Sales ${ }^{b}$ & 4.41 & 1.04 & 0.34 & -- & & & & & & & & \\
\hline 3. Age & 36.90 & 16.72 & 0.14 & 0.49 & -- & & & & & & & \\
\hline 4. Prior performance (ROA) & 0.05 & 0.01 & 0.04 & 0.17 & 0.28 & -- & & & & & & \\
\hline 5. Leverage & 2.71 & 0.88 & -0.02 & 0.01 & -0.04 & -0.26 & -- & & & & & \\
\hline 6. Advertising & 0.02 & 0.01 & -0.03 & 0.05 & -0.03 & -0.07 & -0.04 & -- & & & & \\
\hline 7. R \& D & 0.02 & 0.01 & 0.02 & 0.07 & 0.03 & 0.15 & -0.01 & 0.08 & -- & & & \\
\hline 8. Trust & 0.00 & 1.00 & 0.06 & 0.05 & 0.09 & 0.41 & -0.08 & -0.03 & 0.05 & -- & & \\
\hline 9. Environmental uncertainty & 0.00 & 1.00 & -0.10 & -0.01 & -0.08 & -0.39 & 0.05 & 0.09 & -0.12 & 0.00 & -- & \\
\hline 10. Knowledge intensity & 0.00 & 1.00 & -0.03 & 0.16 & 0.16 & 0.44 & -0.17 & 0.00 & 0.03 & 0.00 & 0.00 & - \\
\hline
\end{tabular}

${ }^{a} n=3694$; Pearson correlations $>|.090|$ significant at .05 level

${ }^{\mathrm{b}}$ Natural logarithm. 
Table 5. Results of panel data logit estimation (DV: alliance formation =1)

\begin{tabular}{|c|c|c|c|c|c|c|c|c|c|c|}
\hline \multirow{2}{*}{ Variables $^{\mathrm{a}}$} & \multicolumn{2}{|c|}{ Model 1} & \multicolumn{2}{|c|}{ Model 2} & \multicolumn{2}{|c|}{ Model 3} & \multicolumn{2}{|c|}{ Model 4} & \multicolumn{2}{|c|}{ Model 5} \\
\hline & Beta & SE & Beta & SE & Beta & SE & Beta & SE & Beta & SE \\
\hline$\overline{\text { Sales }^{\mathrm{a}}}$ & $2.321 * * *$ & 0.238 & $3.001 * * *$ & 0.317 & $3.131 * * *$ & 0.328 & $3.011 * * *$ & 0.314 & $3.170 * * *$ & 0.328 \\
\hline Age & $-0.046 * * *$ & 0.014 & $-0.060 * * *$ & 0.017 & $-0.064 * * *$ & 0.017 & $-0.059 * * *$ & 0.017 & $-0.064 * * *$ & 0.017 \\
\hline Prior performance (ROA) & $-0.887 * * *$ & 0.190 & $-2.105^{* * *}$ & 0.274 & $-2.146^{* * *}$ & 0.280 & $-2.070 * * *$ & 0.274 & $-2.099 * * *$ & 0.283 \\
\hline Leverage & $-0.549 * * *$ & 0.151 & $-0.571 * * *$ & 0.177 & $-0.619 * * *$ & 0.179 & $-0.555^{* *}$ & 0.177 & $-0.594 * * *$ & 0.179 \\
\hline Advertising & -0.191 & 0.124 & -0.068 & 0.152 & -0.050 & 0.155 & -0.052 & 0.152 & -0.031 & 0.155 \\
\hline $\mathrm{R} \& \mathrm{D}$ & -0.049 & 0.125 & -0.138 & 0.156 & -0.195 & 0.162 & -0.137 & 0.155 & -0.196 & 0.163 \\
\hline Environmental uncertainty $(\mathrm{EU})^{\mathrm{b}}$ (H1) & & & $-2.038 * * *$ & 0.249 & $-1.981 * * *$ & 0.257 & $-2.019 * * *$ & 0.243 & $-1.933 * * *$ & 0.255 \\
\hline Knowledge Intensity (KI) ${ }^{\mathrm{b}}$ (H2) & & & 0.124 & 0.193 & 0.047 & 0.192 & 0.078 & 0.194 & -0.030 & 0.195 \\
\hline Trust $^{\mathrm{b}}(\mathbf{H 3})$ & & & $1.685^{* * *}$ & 0.215 & $1.678 * * *$ & 0.219 & $1.709 * * *$ & 0.216 & $1.718^{* * *}$ & 0.223 \\
\hline EU*Trust (H4) & & & & & $-0.643 * * *$ & 0.175 & & & $-0.735 * * *$ & 0.185 \\
\hline KI*Trust (H5) & & & & & & & $0.368 * *$ & 0.154 & $0.446^{* *}$ & 0.155 \\
\hline Log likelihood & -876.93 & & -783.21 & & -775.99 & & -780.29 & & -771.88 & \\
\hline Wald $\chi^{2}$ & 108.6 & & 142.93 & & 140.67 & & 149.35 & & 144.63 & \\
\hline Wald test $\chi^{2}$ & & & 34.29 & $9 * * *$ & 32.03 & $3 * * *$ & 40.71 & | $* * *$ & 35.99 & $* * *$ \\
\hline
\end{tabular}

$\frac{\text { Wald test } \chi^{2}}{n=3694 \text { firm-year; }}$

${ }^{\mathrm{a}}$ Transformed to natural logarithm.

${ }^{\mathrm{b}}$ Factor scores from principal component analysis.

$* p<.05$.

$* * p<.01$.

$* * * p<.001$ (all two-tailed). 


\section{Appendix A: Survey Scales}

Environmental Uncertainty $(\alpha=.723)$

1. The industry the firm is operating in is characterized by low entry barriers.

2. Your firm is operating in a market characterized by fast changing and hard to predict market demands.

3. The technological standards in your industry are changing at a high pace.

Knowledge Intensity of the Production Process $(\alpha=.667)$

1. Specialized knowledge and technology required for your production process is easily available in the market (reverse coded).

2. The economic value added during the production process is high.

3. Special knowledge required for the production process is equally divided among different members in the organization.

4. Much time has been spent acquiring the procedures necessary for the demands of your customers.

Interorganizational Trust $(\alpha=.642)$

1. In contact with business partners you never had the feeling of being misled.

2. The longer the business relationship with a partner lasts, the better and faster the understanding of the partner is.

3. You remain cautious to new business partners until they prove that they are trustworthy. (reverse coded)

4. You cover everything in watertight contracts while dealing with your business partners. (reverse coded) 